\title{
Kenyans protest at being left off AIDS patent
}

Wachira Kigotho, Nairobi

The terms of a collaboration on a potential HIV vaccine, between a British research team and the University of Nairobi, are to be revised after the Kenyan scientists complained that their names had been excluded from a patent application on the vaccine.

The original patent on the subtype A DNA candidate vaccine was filed last year by the UK Medical Research Council in the names of Andrew McMichael and Tomas Hanke, of Oxford University's Institute of Molecular Medicine.

The vaccine is based on a mechanism by which certain HIV-resistant prostitutes in Nairobi appear to be immune to the disease. McMichael and Hanke have been primarily responsible for identifying the molecular basis of this mechanism and building it into the vaccine.

Under an agreement reached with the University of Nairobi two weeks ago, a new memorandum will be drawn up recognizing the contribution of scientists in the university's Department of Microbiology. These researchers have been recording the T-cell responses among prostitutes in the Majengo slums of Nairobi for more than a decade.

The dispute arose from the fact that, although the two teams work closely together - trials of the vaccine are already under way in Oxford, and are due to start in Kenya shortly - the Oxford researchers had not told their African colleagues that they were applying for the patent.

"As soon as we realized our names were not included, we entered into correspondence with our partners to ensure that we were reflected as being among the researchers," says Job Bwayo, head of microbiology and team leader of the AIDS vaccine initiative programme at the University of Nairobi.

According to McMichael, his research team took out the patent primarily to prevent other organizations from doing so. He says that his and Hanke's names are the only ones on the application because its novel technical content - primarily the sequence of the construct — was based entirely on work carried out in Oxford.

"There has been no intention of shutting out the Kenyans from the fruits of the research," says McMichael, although he admits that "we should have raised the patent issue much earlier".

He adds that one aim of seeking a patent was to ensure that, if the clinical trials prove successful, the vaccine would not be marketed at a profit, but at a price that most Africans would be able to afford.

It has now been agreed that the original memorandum of understanding will be modified to recognize the contribution of

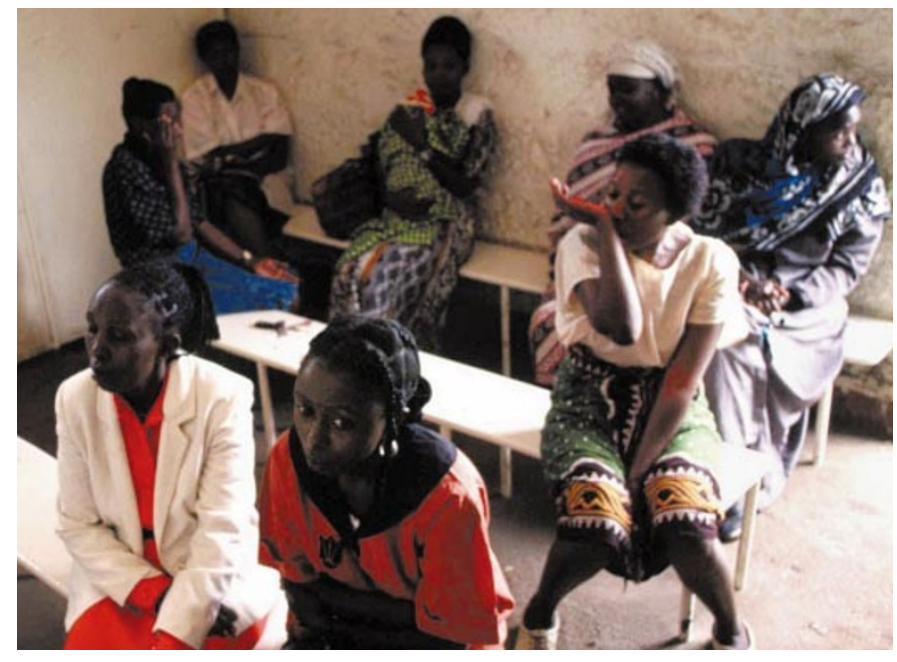

Prostitutes in Nairobi wait for a medical check-up. A potential HIV vaccine has been developed from Kenyan prostitutes immune to the virus.

Bwayo and his colleagues Omu Anzala and Jeckoniah Ndinya-Achola, who have been involved in the broader research behind the potential vaccine.

Talks chaired by the vice-chancellor of the University of Nairobi, Francis Gichaga, have also led to an agreement to set up a task force consisting of patent and intellectual-property experts from the two universities and members of the New York-based International Aids Vaccine Initiative (IAVI), the main sponsor of the clinical trials.

One issue still to be addressed is how to benefit the 60 prostitutes whose immune systems provided the knowledge to develop the vaccine. "We have not forgotten them," says Anzala, the project's programme manager in Nairobi.

A statement issued by the University of Nairobi, the UK Medical Research Council and IAVI, while acknowledging "shortfalls" in the current memorandum, also stresses that "this patent was filed in good faith to protect the candidate DNA vaccine from unauthorized third-party exploitation".

http://www.iavi.org

\section{Puffer fish joins genome stampede}

David Cyranoski, Tokyo

\section{\& Paul Smaglik, Washington}

An international consortium led by the USbased Joint Genome Institute last week announced plans to sequence the genome of the puffer fish Fugu rubripes. It is hoped that this will offer a cheap and fast route to unravelling many of the mysteries of the human genome.

Since the draft sequence of the human genome was announced in June, annotation of the sequence - allocating genes to pieces of sequence - has progressed relatively slowly. Comparative analysis with other vertebrate genomes is thought to be the key to illuminating many of these genes and regulatory sequences, and another consortium has already announced that it will produce a draft of the mouse genome by next March (see Nature 407, 663-664; 2000).

The Fugu genome, also expected to be ready in draft form by next March or April, should make finding the genes a much faster process than if only the human and mouse genomes were to hand. "It's going to have a pretty dramatic effect," says Trevor Hawkins, deputy director of the Joint

^ ๔ 2000 Macmillan Magazines Ltd

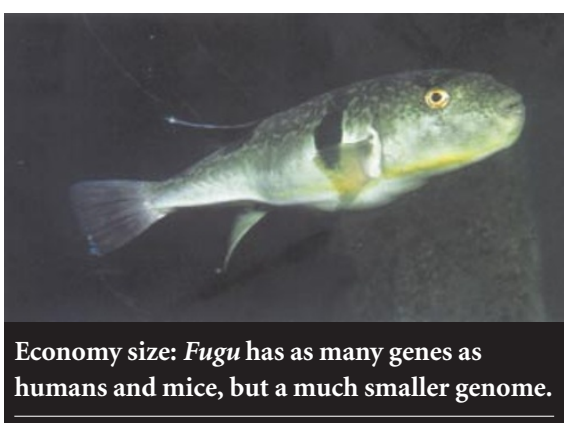

Genome Institute (JGI). "I can't quantify it, but it's going to be pretty amazing."

The JGI, which is based at the Lawrence Berkeley, Lawrence Livermore and Los Alamos national laboratories, will use a procedure called the whole-genome shotgun technique. This breaks the genome into fragments, after which 84 automated sequencers will analyse the $\mathbf{4 0 0}$ million base pairs of DNA in the Fugu genome. Raw sequence data will be released every 24 hours, in accordance with the public project's policy. Scientists can then use these gene fragments to run searches against genes or potential genes in other organisms. 
- By March, the JGI should have sequenced the fish's genome at least three times over, covering $95 \%$ of the genome. This should provide enough data to assemble the fragments into contiguous stretches of DNA, and allow comparisons with the mouse and human genomes.

"I want to take it higher," says Hawkins. Higher coverage, perhaps to four or five times, would result in longer stretches of unbroken DNA, and therefore better comparisons.

Other members of the consortium include Singapore's Institute of Molecular and Cell Biology (IMCB), the US Institute of Systems Biology in Seattle, the UK Human Genome Mapping Project Resource Centre, and the US Molecular Sciences Institute in Berkeley, California. They will share the computational load and be responsible for 'finishing' the Fugu genome by putting together the fragments produced by the JGI's shotgun technique. The finishing phase is expected to be complete by the spring of 2002 .

The Fugu genome is thought to have about the same number of genes as the human genome $-60,000$ to 65,000 , according to estimates by IMCB's B. Venkatesh. But the Fugu genes are spread over only 400 million DNA base pairs, compared with some 3 billion base pairs in the human and mouse. "It can be thought of as the minimum set of genes to build a vertebrate," says Venkatesh.

Comparing Fugu and human "is a very cheap way to get a gene catalogue", says Jean Weissenbach, director of the Centre National de Séquençage in Evry, France. This spring, Weissenbach used the partial sequence of a related puffer fish, Tetraodon nigroviridis, to predict that the human genome has $28,000-34,000$ genes. He expects the Fugu sequence to confirm that estimate.

And because that genome contains few repeats or 'junk' DNA, it should be easier to find similar sequences - and hence genes - between Fugu and human. Human, mouse and Fugu genes all share exons - lengths of DNA that code for proteins. But in the two mammalian genomes, some introns stretches of DNA that are not translated into the final protein - also come as part of the package. Having Fugu's sequence will help weed out those noncoding areas, says Weissenbach.

For IMCB's Chris Tan the project is both a way for Singapore to develop in bioinformatics and biocomputation and a way to move genomics beyond sequencing to "really exciting applications and functional analysis". http://jgi.doe.gov/tempweb/programs/fugu.htm

\section{US fusion community 'must end isolation', says panel}

\section{Colin Macilwain, Washington}

The quality of fusion research in the United States is on a par with other areas of the physical sciences, according to an assessment by the National Academy of Sciences. But the fusion community is isolated from other scientists, struggles to attract young talent, and tends to put the pursuit of fusion energy ahead of the pursuit of good science, the academy warns.

The assessment, undertaken by a panel chaired by Charles Kennel, director of the Scripps Institution of Oceanography in La Jolla, California, recommends that fusion scientists make "a systematic effort to reduce [their] scientific isolation".

It also calls on the National Science Foundation to increase its involvement in fusion research - most US magnetic-fusion work is supported by a \$250-million-a-year programme at the Department of Energy (DoE).

DoE officials welcomed the report's endorsement of the quality of science in their programme. But fusion scientists - many of them gathered in Québec City in Canada last week for the American Physical Society's plasma-physics meeting — were taken aback by the harshness of the panel's judgement on the discipline, which it branded as "intellectually isolated from the rest of science".

"Most scientists funded by the program do not, in general, actively participate in the wider scientific culture," says the executive summary of the panel's report. "As a result, the flow of scientific information both out of and into the field has stagnated."

But in its main finding, the panel said that the general quality of science funded by the DoE magnetic-fusion programme was "easily on a par with other leading areas of contemporary physical science".

Four years ago the fusion programme lost

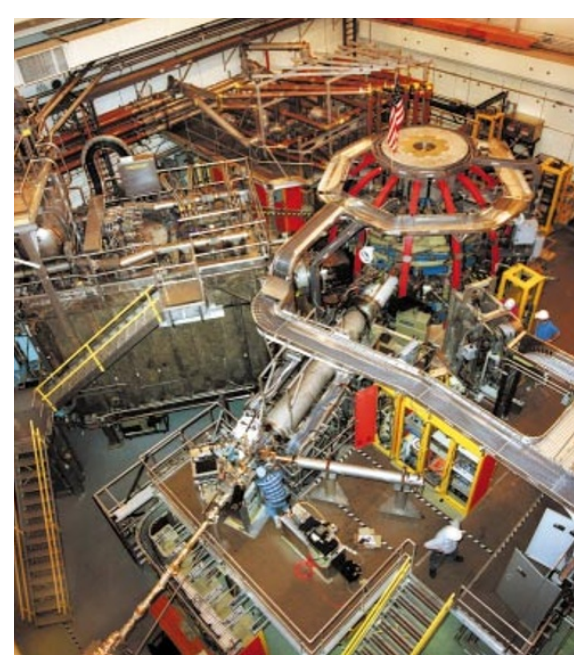

Nice work: the report praised fusion research, such as the National Spherical Torus Experiment.

one-third of its budget and the DoE changed its main goal from developing fusion-based energy sources to improving the scientific understanding of fusion. But according to Kennel, programme resources are still allocated largely to approaches that demonstrate progress towards fusion power.

Some fusion scientists argue that their experiments need to be relevant to fusion power. Magnetic fusion "is a mission-orientated science”, says David Baldwin, senior vice-president of the fusion group at General Atomics in San Diego, California.

But others welcomed the report's call for more emphasis on scientific questions. Bill Dorland, a theorist at the University of Maryland's Institute for Plasma Research, says time on large fusion facilities tends to go to experiments that promise to raise technical performance, rather than understand why performance is restricted.

\section{Whitehead enters into array deal}

Steve Nadis, Boston

The high-tech manufacturers Corning have entered into a \$10 million research partnership with the Whitehead Institute for Biomedical Research at the Massachusetts Institute of Technology. Corning will give the Whitehead \$2.5 million for each of the next four years for the development of what the company calls "the next generation of DNA microarrays and other tools of the post-genome world".

The partnership aims to produce DNA chips that can analyse 10,000 human genes at a time and to develop protein arrays to facilitate the simultaneous study of thousands of proteins.

"There is a critical need for researchers in academia and industry to collaborate in the battle against human disease in order to develop technologies with the potential to revolutionize medical science," says Richard Young, a biologist at the Whitehead and MIT who will direct the project. "We intend to use technologies developed through the joint initiative with Corning to lay a foundation for better drugs and vaccines." 